\title{
ATMOSPHERIC METHANE EMISSIONS FOR ARGENTINA. COMPARISON WITH TROPOMI SATELLITE MEASUREMENTS.
}

\author{
S. E. Puliafito ${ }^{1, *}$, L. Berná ${ }^{2}$, A. Lopez-Noreña ${ }^{1}$, R. Pascual ${ }^{1}$, T. Bolaño-Ortiz ${ }^{1}$ \\ ${ }^{1}$ Universidad Tecnológica Nacional / CONICET, Mendoza, Argentina - (enrique.puliafito, ailopezn.ail, rominapascual, \\ tomasrbo)@gmail.com \\ ${ }^{2}$ Universidad Tecnológica Nacional / ANPCYT, Mendoza, Argentina - lucasberna@gmail.com
}

KEY WORDS: Emissions inventory, Methane emissions, TROPOMI, EDGAR, Argentina, air quality

\begin{abstract}
:
Methane emissions have very important effect on global radiative forcing. Therefore, reducing these emissions has been proposed as an effective short-term strategy to mitigate global warming, in parallel with reductions in long-lived carbon dioxide $\left(\mathrm{CO}_{2}\right)$ for longterm temperature stabilizations. In this context, Argentina emits $3645 \mathrm{Gg}_{\text {of }} \mathrm{CH}_{4}$ mainly from livestock production, biomass burning and natural gas production. Since 2018, TROPOMI instruments provide global coverage on methane column-average mole fraction of dry air $\left(\mathrm{XCH}_{4}\right)$, and height profiles of methane concentrations. We compare two available methane inventory: a national (a high resolution of own ellaboration: GEAA) and an international (EDGAR) emissions database with TROPOMI measurements. By performing inverse satellite retrieval we evaluate the ability of remote sensing information to detect possible hotspot methane emissions and compare these results with the two inventories. From these analyzes, we observe that the latitudinal averages of the continental sector increase at a rate of $10 \mathrm{ppb} /$ degree, from south to north, while the maritime sector remains constant. From a temporary perspective, the average monthly concentration amplitude range varies 40 to $50 \mathrm{ppb}$, with minimum values in March and maximum values in September.
\end{abstract}

\section{INTRODUCTION}

Short-lived climate pollutants (SLCP) including methane (CH4), black carbon (BC), tropospheric ozone, and hydrofluorocarbons (HFCs), have very important effect on global radiative forcing (Shindell et al., 2004; Etminan et al., 2016). Reducing these emissions has been proposed as an effective short-term strategy to mitigate global warming, together with reductions in long-lived carbon dioxide $\left(\mathrm{CO}_{2}\right)$ for long-term temperature stabilizations. Without reductions in both $\mathrm{CO}_{2}$ and SLCPs, temperature increases are likely to exceed $1.5^{\circ} \mathrm{C}$ during the $2030 \mathrm{~s}$ and exceed $2^{\circ} \mathrm{C}$ by mid-century (Shindell et al, 2017; Shoemaker et al., 2013, Collins et al, 2013, Ramanathan and $\mathrm{Xu}, 2010$ ). On the other hand, methane is also a precursor to the formation of surface ozone, which affects population health (West et al., 2006; Isaken et al., 2009).

Atmospheric observations have shown significant increases in methane levels during the 20th century at a constant rate of approximately $15 \mathrm{ppb} / \mathrm{year}$, with some stabilization in the 1990s and growing rapidly after 2006 (CDIAC, 2019) Blake, 2013; IPCC 2007, Fowler at al., 2009). The causes of these slope changes are not well known, but they do show a complex feedback of methane and biosphere. This important feedback and uncertainties about methane sources and sinks have motivated many researchers to conduct more detailed methane inventories and analysis.

Argentina emits $3200 \mathrm{Gg}$ of $\mathrm{CH}_{4}$ mainly from livestock production, biomass burning and natural gas production. Since 2018, TROPOMI instruments provide global coverage on methane column-average mole fraction of dry air $\left(\mathrm{XCH}_{4}\right)$, and height profiles of methane concentrations. We compare in this paper, two available methane inventory: a national (high resolution of own ellaboration, here called "GEAA") and an international Emissions Database for Global Atmospheric Research (EDGAR) (Janssens-Maenhout et al., 2017) emissions database: EDGARv4.2FT2010; with the TROPOspheric Monitoring Instrument (TROPOMI), on board the Copernicus Sentinel-5 Precursor satellite, (TROPOMI, 2018).

\section{INVENTORIES}

\subsection{National methane inventories}

In South America, there are national greenhouse gases (GHG) inventories submitted to the Intergovernmental Panel on Climate Change (IPCC) with a spatial resolution of provinces or districts. For Argentina, a national emissions database has been published for GHGs (TNCA, 2016). Air pollutants inventories, including methane, have been compiled for several sectors (GEAA inventory) at a high resolution $0.025^{\circ} \times 0.025^{\circ}$ (Puliafito et al., 2015, 2017, 2019). Castesana et al., (2018) presented a $\mathrm{NH}_{3}$ inventory of agricultural activities with spatial resolution at the district level.

\subsection{EDGAR emissions inventory}

The EDGAR inventory compiles information from emission sources globally at a $0.1^{\circ}$ (lat./long.) resolution. Methane emissions for all sources were compared with the GEAA inventory (Table 1).

\footnotetext{
* Corresponding author
} 

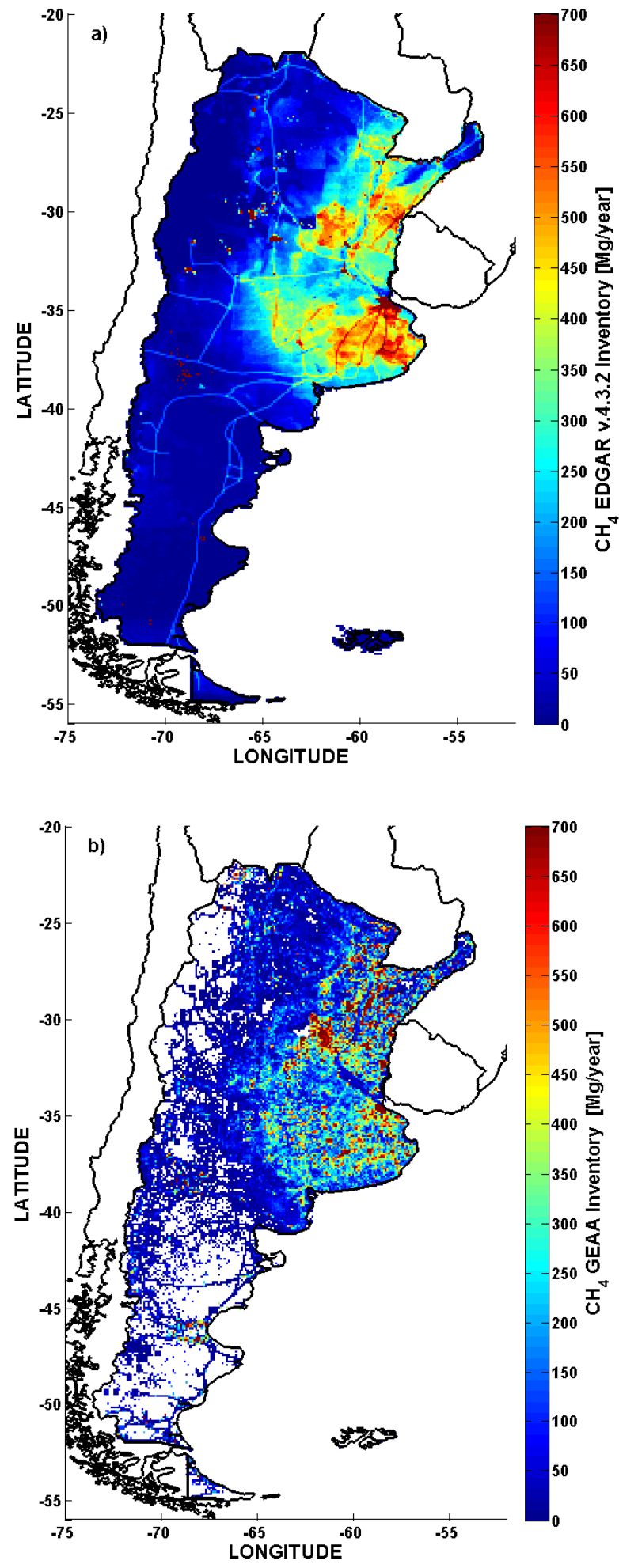

Figure 1. Methane inventory: a) EDGAR, b) GEAA

Figure 1 shows two methane inventories (EDAGR and GEAA). Table 1 shows total emissions by sector for Argentina, while Figure 2 show a series for the three mentioned inventories for years 1990-2016. Notice that EDGAR is only available up to 2012, while TNCA was calculated until 2014 and GEAA is available to 2016 .

Comparing sectoral methane emissions, from enteric fermentation, manure management, biomass burning and rice cultivation, for years 1990-2012; EDGAR averages $3155 \pm 390$ Gg/year; while GEAA averages $3030 \pm 235 \mathrm{Gg} /$ year. Thus, there is a $4 \%$ relative difference between both inventories. However, other discrepancies for $\mathrm{CH}_{4}$ emissions concerning several subsectors were present (i.e. fugitive emissions from oil and gas: EDGAR $864 \mathrm{Gg}$, GEAA: $272 \mathrm{Gg}$ ), rising the differences for all sector (2012) to $1050 \mathrm{Gg}(22 \%)$ : EDGAR: 4557 Gg, GEAA: 3644 Gg. Despite most sectors, have good agreements, spatial distribution presented some differences. Therefore, EDGAR overestimated on average 13\% compared to GEAA and TNCA inventories for the considered period. Estimations of methane emissions corresponding to year 2012 for agriculture, livestock and biomass burning were $3257.46 \mathrm{Gg}$ for EDGAR, 2454.40 for GEAA and $2505.56 \mathrm{Gg}$ for TCNA.

\begin{tabular}{|c|c|c|c|}
\hline Sector & GEAA & EDGAR & TNCA \\
Ref. Year & 2014 & 2012 & 2014 \\
\hline Electricity & 4.58 & 3.08 & 5.56 \\
Transport & 19.40 & 14.68 & 17.26 \\
Residential + & 4.17 & 10.89 & 4.32 \\
Industries & & & \\
Fugitive emissions & 272.13 & 864.67 & 327.23 \\
Enteric & $2,620.23$ & $3,110.61$ & $2,413.74$ \\
Fermentation & & & \\
Manure & 29.14 & 59.86 & 41.65 \\
management & & & \\
Rice cultivation & 30.08 & 27.93 & 28.77 \\
Biomass burning & 39.20 & 59.06 & 93.73 \\
Urban Waste & $\mathbf{6 2 5 . 9 7}$ & 406.14 & 625.97 \\
\hline Total & $\mathbf{3 , 6 4 4 . 9 0}$ & $\mathbf{4 , 5 5 6 . 9 1}$ & $\mathbf{3 , 5 5 8 . 2 5}$ \\
\hline
\end{tabular}

Ref: adapted from Puliafito, et al $(2017,2019)$; (*) includes AWB: Agricultural waste burning. TNCA, (2016); EDGAR: Janssens-Maenhout et al., (2017).

Table 1: Total methane emissions (Gg/year) from all sectors for Argentina 2016.

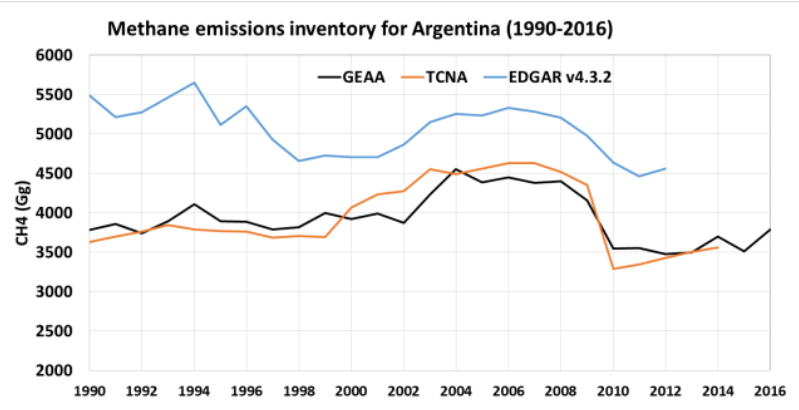

Figure 2. Comparison of methane emissions for Argentina

Since GEAA has a higher spatial resolution $\left(0.025^{\circ}\right.$ lat./long. $)$, this inventory needed to be converted to a $0.1^{\circ}$ resolution to allow an adequate spatial comparison. Therefore, each $0.1^{\circ}$ broad cell was computed by adding all corresponding $0.025^{\circ}$ higher-resolution cells within the circumscribed broaderresolution cell.

EDGAR presented higher values than GEAA in cities and in mountain range (where almost no activity is present). It is observed in Figure 1, that in Patagonia (Southern Argentina latitudes $40^{\circ} \mathrm{S}-55^{\circ} \mathrm{S}$ and western border) EDGAR map show average values around $20 \mathrm{Mg} /$ year, while GEAA show null values for the same regions. A second comparison included the geographical extent of EDGAR (Figure 1a) and GEAA (Figure 
1b) inventories. Both inventories were also compared by totalizing $0.1^{\circ}$ bin latitudinal and longitudinal methane emissions (Figure 3). Also high fugitive emissions from natural gas pipelines can be clearly observed in EDGAR map. EDGAR presented higher values than GEAA specially between $42^{\circ} \mathrm{S}$ $34^{\circ} \mathrm{S}$ and $69^{\circ} \mathrm{W}-66^{\circ} \mathrm{W}$. This area corresponds to a natural gas producing area, whose difference were associated mainly to venting from exploring and productive natural gas wells. This high difference is consistent with Table 1. In fact, years 20102016, have been very active but variable years with respect to oil and natural gas exploration and production, and therefore the differences may be explained by different activity data.

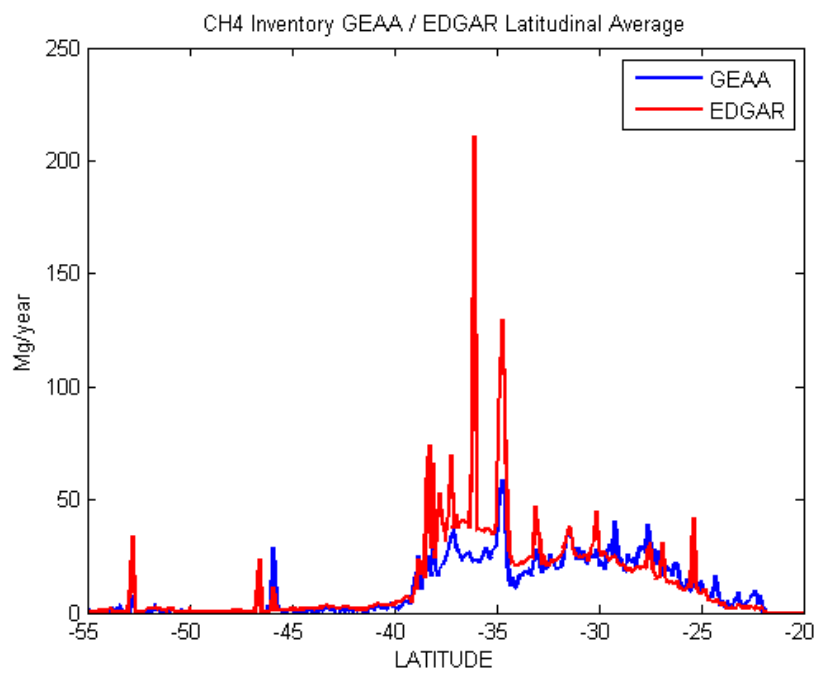

Figure 3. Latitudinal averages for EDGAR and GEAA methane inventory for $0.1^{\circ}$ resolution.

\section{SATELLITE DATA}

\subsection{SCHIAMACHY AND GOSAT}

Global methane data has been published in the form of columnaveraged dry mole fraction $\mathrm{XCH} 4$ from SCIAMACHY (Scanning Imaging Absorption Spectrometer for Atmospheric Chartography, on board ENVISAT, ground resolution: $30 \mathrm{~km} \times$ $60 \mathrm{~km}$ ), years 2002-2009, (Frankenberg et al., 2005, 2011). and GOSAT (Greenhouse gases observing satellite, ground resolution: $10 \mathrm{~km} \times 60 \mathrm{~km}$ ), for years 2009-2018, (Yokota, 2004, Yoshida, 2011, Schepers et al., 2012).

Figure 4 shows monthly zonal mean $\left(20^{\circ} \mathrm{S}-55^{\circ} \mathrm{S}\right)$ of methane column average dry air mixing ration $\mathrm{XCH} 4(\mathrm{ppb})$ from SIAMACHY and GOSAT (2003-2017). The annual averages have varied from $1716 \pm 36 \mathrm{ppb}$ in 2003 to $1780 \pm 27 \mathrm{ppb}$ in 2017. Figure 5 shows the monthly surface concentrations of methane measured at the GAW station (Global Atmospheric Watch Station, from the World Meteorological Organization, operated by the National Meteorological Service of Argentina) at the city of Ushuaia $\left(54.8^{\circ} \mathrm{S}, 64.3^{\circ} \mathrm{W}\right)(\mathrm{GAW}, 2018)$. Monthly average concentration values in Ushuaia had a seasonal amplitude of 40-50 ppb, with minimum values in March and maximum values in September with an average annual rate of increase of $0.35 \%$ (6.2 ppb/year) since 2008. Three slopes are identify: (1994-1999), (2000-2007) and (2008-2017), which agree with global tendencies. Although there are many uncertainties regarding the stable period (2000-2007), Kirschke et al. (2013) attribute it to a reduction-stabilization of global emissions and an increase in stabilization of microbial activity.

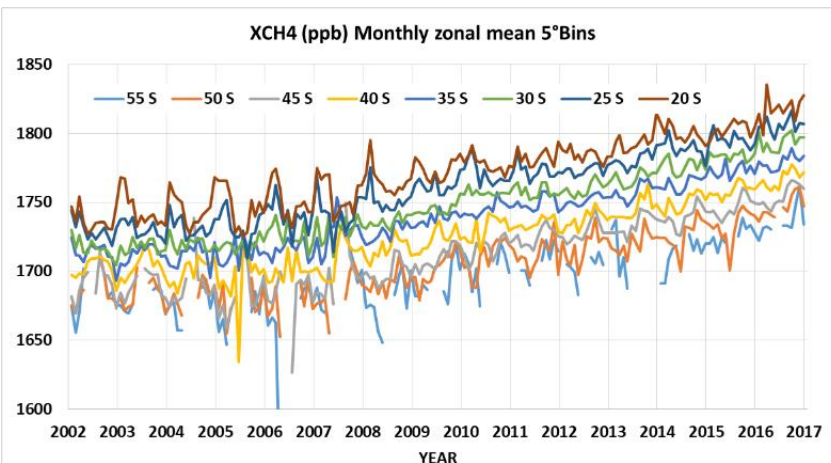

Figure 4. Zonal mean (15S-53S) methane column average dry air mixing ration (ppb) from SIAMACHY (2003-2009) and GOSAT (2009-2018).

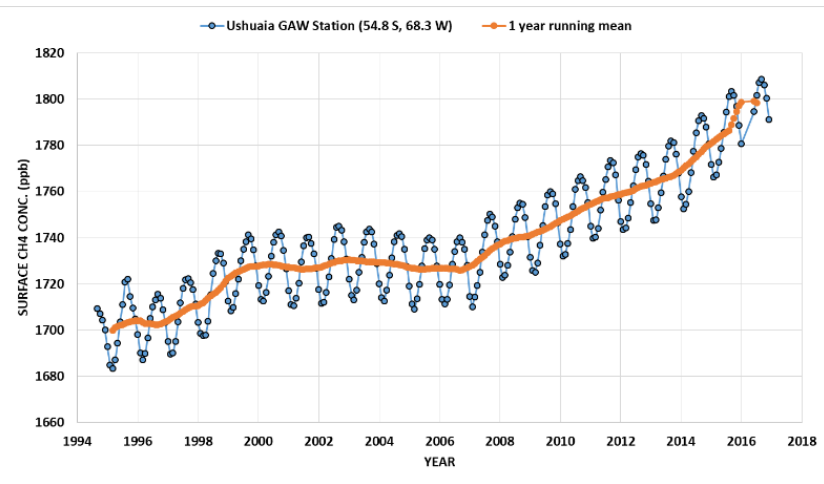

Figure 5. monthly surface concentrations of methane measured at the GAW station in Ushuaia $\left(54.8^{\circ} \mathrm{S}, 64.3^{\circ} \mathrm{W}\right)(\mathrm{GAW}, 2018)$.

\subsection{TROPOMI measurements}

The newly TROPOMI instruments provided information (since 2018) on methane column-average mole fraction of dry air (XCH4), and height profiles of methane concentrations, with ground resolution of $7 \mathrm{~km} \times 3.5 \mathrm{~km}$. For TROPOMI XCH4 data, we used Level 2 product (Apituley et. al., 2017) over Argentina between May 2018 and April 2019 with a resolution of $0.25^{\circ} \times 0.25^{\circ}$. TROPOMI data covered almost the entire spatial extension of Argentina with sufficient number of pixels.

Figure 6 shows annual average of XCH4 over Argentina using TROPOMI (May 2018- April 2019). We used TROPOMI data because of its higher spatial resolution and coverage (than SIAMACHY and GOSAT). It can be seen that methane concentrations increased from south to north (in the SE-NW direction) coinciding over the continental sector with an average rate of $2.2 \pm 0.5 \mathrm{ppb} /$ degree $(\mathrm{N}-\mathrm{S})$ and $1.4 \pm 0.6 \mathrm{ppb} /$ degree $(\mathrm{W}$ E). To qualitativelly compare the methane inventory with satellite data we followed Jacob et al, (2016) (i.e. Eq. 13 and Table 2) inverse calculation using TROPOMI data. A mean methane enhancement $\Delta \mathrm{XCH}_{4}$ is estimated by subtracting a background to the satellite data. 

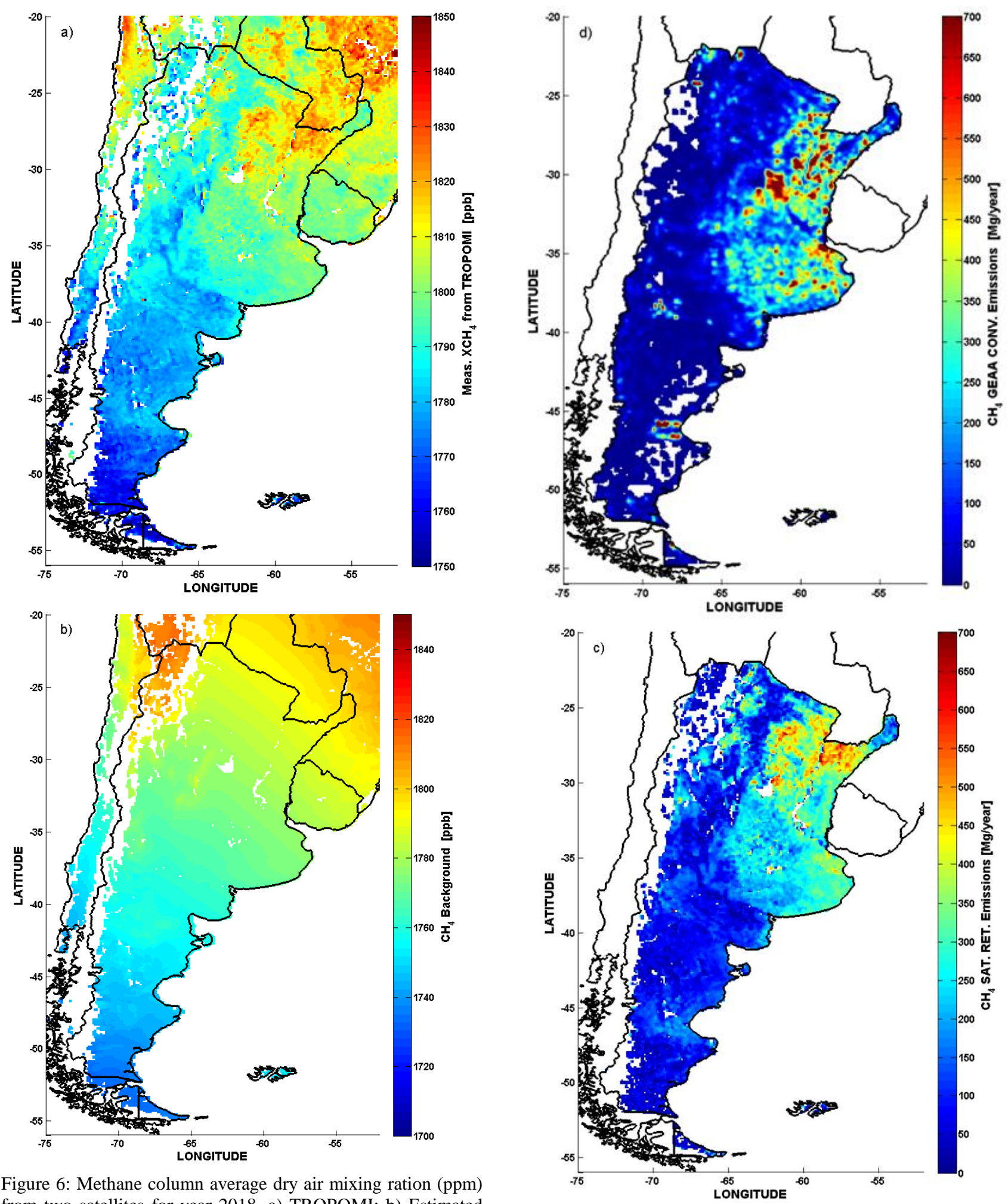

Figure 6: Methane column average dry air mixing ration (ppm) from two satellites for year 2018. a) TROPOMI; b) Estimated background; c) methane enhancement $\triangle \mathrm{XCH}_{4}$ from satellite; d) methane enhancement $\triangle \mathrm{XCH}_{4}$ from inventory 
This background (Figure 6b) is calculated as a plane (slope $=$ $0.09 \mathrm{ppb} /{ }^{\circ}$ Lat, initial value $\left.=1760 \mathrm{ppb} @ 56 \mathrm{~S}, 75 \mathrm{~W}\right)$, which increasead from south to north. This values are consistent with slopes calculated from SCHIAMACHY and GOSAT (Figure 4). The retrieved emission map (Figure 6c) was estimated using Eq. 13 from Jacob et al., (2016) (W=100 km, pressure map from TROPOMI, and $\mathrm{u}=23$ ), which should be compared to Figure $6 \mathrm{~d}$. This is calculated as a smoothed map of Figure 1b, using a gaussian convolution of $0.3^{\circ}$. Figure $6 \mathrm{c}$, gives a qualitative insight into the methane emissions inventory, capturing the main area of emissions: livestock production and agriculture in the central area $(38-32 \mathrm{~S}, 40-45 \mathrm{~W})$ and biomass burning at North East areas $(27-25 \mathrm{~S}, 60-57 \mathrm{~W})$. It can be seen, that the GEAA inventory understimated the $\mathrm{CH} 4$ emissions in the NE area. Probably the retrieval calculation is including methane transport from biomass burning from other areas (i.e Amazonia), as it is shown in Figure 6a, but not included in the present inventory.

\section{DISCUSSION}

Argentina is an important agriculture and livestock producer, reaching 123 million tons of crops annually and breeding 52 million heads of cattle, emitting in year $2016,2186.10 \mathrm{Gg}$ methane from the beef cattle sector, $288.40 \mathrm{Gg}$ from dairy cattle sector and another $204.58 \mathrm{Gg}$ from other livestock production, totaling $2679.08 \mathrm{Gg}$. This emission represents $83 \%$ of the $3198.45 \mathrm{Gg}$ total national methane emissions (all sectors) and $27 \%$ of total national GHG emissions. Other sectors as the energy-producing sector (electricity and fugitive form oil/natural gas extraction) added $278 \mathrm{Gg}$ of methane.

A high-resolution methane emissions inventory for Argentina (GEAA) was compared to an international database (EDGAR) and The Third National Greenhouse Report (TNCA, 2016). There are two main differences, however, with the two abovementioned inventories: a) GEAA inventory includes species that affect air quality and b) it display them on a higher spatial resolution map $\left(0.025^{\circ}\right.$ resolution). Compared to EDGAR international emissions database $\left(0.1^{\circ}\right.$ spatial resolution $)$ the methane emissions for Argentina for all sector gave an average difference of $13 \%$ and a spatial uncertainty of $50 \mathrm{Mg} /$ year/cell.

The present study also included the analysis SCIAMACHY, GOSAT AND TROPOMI satellite data for the analysis of methane concentrations in the Argentine territory. The aim of this analysis was to explore if methane emissions could be detected from inverse modelling from satellite sensors.

\section{ACKNOWLEDGEMENTS}

This work was supported by Universidad Tecnológica Nacional (UTN IFI Projects PID 1799 and 1487, CONICET (PIP 112 201101 00673) and Agencia FONCYT (PICT 2016 1115). All data requests should be addressed to the first author.

\section{REFERENCES}

Apituley, A., Pedergnana, M., Sneep, M., Pepijn Veefkind, J., Loyola, D., Hasekamp, O., 2017: Sentinel-5 precursor/TROPOMI Level 2 Product User Manual Methane, SRON-S5P-LEV2-MA-001,

http://www.tropomi.eu/sites/default/files/files/Sentinel-5P-
Level-2-Product-User-Manual-Methane.pdf, Last accesed, Sept. 2019.

Blake. D., 2013. Methane, Nonmethane Hydrocarbons, Alkyl Nitrates, and Chlorinated Carbon Compounds including 3 Chlorofluorocarbons (CFC-11. CFC-12. and CFC-113) in Whole-air Samples. Carbon Dioxide Information Analysis Center. Oak Ridge National Laboratory. U.S. Department of Energy. Oak Ridge Tenn.. U.S.A. http://cdiac.essdive.lbl.gov/trends/otheratg/blake/blake.html

Butz A., Guerlet S., Hasekamp O., Schepers D., Galli A., Aben I., Frankenberg C., Hartmann J., Tran H., Kuze A., Keppel-Aleks G., Toon G., Wunch D., Wennberg P.,Deutscher N., Griffith D., Macatangay R., Messerschmidt J., Notholt J. and Warneke T., 2011. Toward accurate CO2 and CO4 observations from GOSAT, Geophys. Res. Lett., 38, L14812, https://doi:10.1029/2011GL047888

Castesana, P., Dawidowski, L., Finster, L., Gómez, D., Taboada, M., 2018. Ammonia emissions from the agriculture sector in Argentina; 2000-2012, Atmospheric Environment 178, 293-304. https://doi.org/10.1016/j.atmosenv.2018.02.003 CDIAC (2019): NOAA-CDIAC data http://cdiac.essdive.lbl.gov/methane.html

Collins, M., R. Knutti, J. Arblaster, J.-L. Dufresne, T. Fichefet, P. Friedlingstein, X. Gao, W.J. Gutowski, T. Johns, G. Krinner, M. Shongwe, C. Tebaldi, A.J. Weaver, and M. Wehner, 2013: Long-term climate change: Projections, commitments and irreversibility. In Climate Change 2013: The Physical Science Basis. Contribution of Working Group I to the Fifth Assessment Report of the Intergovernmental Panel on Climate Change. T.F. Stocker, D. Qin, G.-K. Plattner, M. Tignor, S.K. Allen, J. Doschung, A. Nauels, Y. Xia, V. Bex, and P.M. Midgley, Eds. Cambridge University Press, pp. 1029-1136, doi:10.1017/CBO9781107415324.024.

Etminan M., G. Myhre, E. J. Highwood and K. P. Shine., 2016. Radiative forcing of carbon dioxide methane and nitrous oxide: A significant revision of the methane radiative forcing. Geophys. Res. Lett. 43. 12.614-12.623. https://doi:10.1002/2016GL071930

Fowler D.; Pilegaard. K.; Sutton. M.A.; Ambus. P.; Raivonen. M.; Duyzer. J.; Simpson. D.; Fagerli. H.; Fuzzi. S.; Schjoerring. J.K.; et al., 2009. Atmospheric composition change: Ecosystems-Atmosphere interactions. Atmos. Environ. 43.5193-5267. https://doi.org/10.1016/j.atmosenv.2009.07.068

Frankenberg C., Aben I., Bergamaschi P., Dlugokencky E., van Hees R., Houweling S., van der Meer P., Snel R., and P. Tol., 2011. Global column-averaged methane mixing ratios from 2003 to 2009 asderived from SCIAMACHY: Trends and variability, J. Geophys. Res., 116, D04302, https://doi:10.1029/2010JD014849.

Frankenberg C., Meirink J., van Weele M., Platt U., and Wagner T., 2005. Assessing methane emissions from global space-borne observations, Science, 308, 1010-1014. https://doi:10.1126/science.1106644

GAW-Global Atmospheric Watch, 2018. A program from World Meteorological Organization. http://www.wmo.int/pages/prog/arep/gaw/ghg/ghgbull06_en.ht 
$\mathrm{ml}$ and World Data Center for Greenhouse Gases (WDCGG) https://gaw.kishou.jp/

IPCC - The Intergovernmental Panel on Climate Change. 2007. The Physical Science Basis. Contribution of Working Group I to the Fourth Assessment. Report of the Intergovernmental Panel on Climate Change; Solomon S., Qin D., Manning M., Chen Z., Marquis M., Averyt K.B., Tignor M., Miller H.L, Eds.; Cambridge University Press: Cambridge. UK/New York. NY. USA.

Isaksen I., Granier. C., Myhre. G., Berntsen T.K., Dalsøren S.B., Gauss M., Klimont Z., Benestad R., Bousquet P., Collins W., Cox T., Eyring V.,Fowler. D., Fuzzi S., Jöckel P., Laj. P., Lohmann U., Maione M., Monks P., Prevot A., Raes F., Richter A., Rognerud B., Schulz M., Shindell D., Stevenson D., Storelvmo T., Wang W.-C., 2009. Atmospheric composition change: Climate-Chemistry interactions, Atmospheric Environment, 43, (33), pp. 5138-5192. https://10.1016/j.atmosenv.2009.08.003

Jacob, D., Turner,A., Maasakkers,J., Sheng, J.,Sun, K., Liu, X., Chance, K., Aben, I., McKeever, J., and Frankenberg, C. Satellite observations of atmospheric methane and their value for quantifying methane emissions. Atmos. Chem. Phys., 16, 14371-14396, 2016, doi:10.5194/acp-16-14371-2016

Janssens- Maenhout G., Crippa M., Guizzardi D., Muntean M., Schaaf E., Dentener F., Bergamaschi P., Pagliari V., Olivier J., Peters J., van Aardenne J., Monni S., Doering U., Petrescu A., 2017. EDGARv4.3.2 Global Atlas of the three major Greenhouse Gas Emissions for the period 1970-2012. Earth Syst. Sci. Data Discuss. https://doi.org/10.5194/essd-2017-79.

Puliafito, S. E.; Allende, D. Castesana, P., Ruggeri, M., 2017. High-resolution atmospheric emission inventory of the argentine energy sector. Comparison with Edgar global emission database. Heliyon 3 e00489. https://doi.org/10.1016/j.heliyon.2017.e00489

Puliafito, S.E., Allende, D., Pinto, S., Castesana, P., 2015. High resolution inventory of GHG emissions of the road transport sector in Argentina, Atmospheric Environment 101, 303-311, https://doi.org/10.1016/j.atmosenv.2014.11.040

Puliafito, S. E., Bolaño-Ortiz, T. Berná, L., Pascual-Flores, R., 2019. High-resolution inventory of atmospheric emissions from livestock production, agriculture, and biomass burning sectors of Argentina, Atmospheric Environment, https://doi.org/10.1016/j.atmosenv.2019.117248

Ramanathan, V. and Xu, Y., 2010, The Copenhagen Accord for limiting global warming: Criteria, constraints, and available avenues,

8062; https://doi.org/10.1073/pnas.1002293107

Schepers D., Guerlet S., Butz A., Landgraf J., Frankenberg C., Hasekamp O., Blavier J., Deutscher N., Griffith D., Hase F., Kyro E., Morino I., Sherlock V., Sussmann R. and I. Aben I., 2012. Methane retrievals from Greenhouse Gases Observing Satellite (GOSAT) shortwave infrared measurements: Performance comparison of proxy and physics retrieval algorithms, J. Geophys. Res.,117, D10307, https://doi:10.1029/2012JD017549
Shindell, D., Borgford-Parnell, N., Brauer, M., Haines, A., Kuylenstierna, J., Leonard, S., Ramanathan, V., Ravishankara, A., Amann, M., Srivastava, L., 2017: A climate policy pathway for near- and long-term benefits, Science 356 (6337): 493-494, May 2017, doi: 10.1126/science.aak9521

Shindell. D.T.. Walter. B.P.. Faluvegi. G., 2004. Impacts of climate change on methane emissions from wetlands. Geophysical Research Letters, 31. L21202. https://doi:10.1029/2004GL021009

Shoemaker, J., Schrag, D., Molina, M., Ramanathan, V., 2013, What Role for Short-Lived Climate Pollutants in Mitigation Policy? Science 342 (6164), 1323-1324, Dec. 2013, doi: $10.1126 /$ science. 1240162

TCNA (2016) Argentina Third National Greenhouse Report to UNFCCC., 2016. www.ambiente.gob.ar/tercera-comunicacionnacional/

TROPOMI (2018): TROPOspheric Monitoring Instrument: http://www.tropomi.nl/?lang=en, last Access October 2019).

West I.J., Fiore A., Horowitz L., Mauzerall D., 2006. Global health benefits of mitigating ozone pollution with methane emission controls PNAS. March 14. vol. 103. no. 11. 39883993. www.pnas.orgcgidoi10.1073pnas.0600201103

Yokota T., Oguma H., Morino I., Higurashi A., Aoki T., and G. Inoue., 2004. Test measurements by a BBM of the nadirlooking SWIR FTS aboard GOSAT to monitor CO2 column density from space, Proc. SPIE Int. Soc. Opt. Eng., 5652, 182.

Yoshida, Y., Y. Ota, N. Eguchi, N. Kikuchi, K. Nobuta, H. Tran, I. Morino, and T. Yokota., 2011. Retrieval algorithm for $\mathrm{CO} 2$ and $\mathrm{CO} 4$ column abundances from short-wavelength infrared spectral observations by the greenhouse gases observing satellite, Atmos. Meas. Tech., 4, 717-734; https://doi.org/10.5194/amt-4-717-2011 